\title{
Experimental Research on Durability Properties of High Volume Fly Ash Concrete with Polypropylene Fibre
}

\author{
D. Jayalin, N.Vellingiri, S.Janaki Raman
}

\begin{abstract}
This study focuses on the influence of the durable properties of Conventional concrete and High volume fly ash concrete. Fly ash is replaced in various percentages as $0 \%, 40 \%, 50 \%, 55 \%$ and $60 \%$ by the weight of ordinary Portland cement in addition to that polypropylene fibre of $0.2 \%$ is added for improving the strength and Durability of concrete. Water absorption test, chloride resistance test, sulphateresistance test and Rapid Chloride Penetration test (RCPT) were evaluated. The test results show that the addition of high volume fly ash and polypropylene fibre improves the flexural strength and Durability of concrete. Fly Ash replacement of 55\% by the weight of cement is considered as the optimum replacement level
\end{abstract}

Key words:- cement;fly ash;polypropylene fibres;flexural strength;chlorideresistance: sulphate resistance: water absorption

\section{INTRODUCTION}

Concrete plays a vital role in the construction field in the modern world. Concrete incorporates large amount of natural resources as aggregates and cement with water. Cement is the main ingredient of concrete. Cement production consumes huge energy and causes about $7 \%$ of total green-house gas emission in the world. Each one ton of Portland cement production generates about one ton of $\mathrm{CO} 2$ emissions, which is a green-house gas. The environmental issues related with green-house gases emissions and depletion of natural resources play and important role in the sustainable development of concrete and construction industry. Hence, utilization of supplementary cementitious materials such as fly ash, slag and silica fume is being researched extensively over the last few decades to enhance durability and sustainability of concrete.

Fly ash is a byproduct from coal based thermal power plants. It has been generally considered a waste material in the past and disposal of which has posed numerous ecological and environmental problems. However, recent researches have shown that fly ash has potential to act as invaluable ingredient in cement and concrete. The fly ash is now considered as a resource material rather than a waste in civil engineering and material science. In addition fly ash can be gainfully used for various other applications.

In developing countries like India power generation is most important requirement for economic and social development. In India, about $67 \%$ of electricity

Revised Manuscript Received on April 12, 2019.

D. Jayalin, Assistant Professor,Department of Civil engineering, KarunyaInstitute of Technology and Sciences, Coimbatore, T.N, India.

N.Vellingiri, S. Assistant Professor, Department of Civil engineering, V.S.B. College of engineering technical campus, Coimbatore, T.N, India.

Janaki Raman Assistant Professor,Department of Civil engineering, KarunyaInstitute of Technology and Sciences, Coimbatore, T.N, India. requirements are fulfilled by the coal fired thermal power plants.Thegeneration of $1 \mathrm{MW}$ power with Indian coal results in co-generation of nearly $1800 t$ of fly ash.As per Central Electricity Authority, India, report, 143 no coal fired thermal power plants with installed capacity of $133381 \mathrm{MW}$ produce about 200 million tons of coal ash annually. With the capacity addition of $22282 \mathrm{MW}$ by the end of 2017 , the production of coal ash is estimated to about 185 million tons per year. Nearly 100 million tons of fly ash is being utilized out of 185 million tons generated. Though percentage utilization has gone to nearly $56 \%$ but in absolute terms, very large quantity of fly ash still remains unutilized. This huge quantity is being stored / disposed off in ash pond areas. The ash ponds acquire large areas of agricultural land. Use of fly ash reduces area requirement for pond, thus saving of good agricultural land.

\section{MATERIALS USED:}

\subsection{Cement}

Ordinary Portland cement (OPC) of 53 grade conforming IS $10269-1987^{12}$ was used. The specific gravity of cement was used 3.21 and fineness of cement was $2 \%$.

\subsection{Fly Ash}

Pozzocrete 60 of Class F fly ash acquired from Eklahare Thermal Power station, Nashik conforming to IS 3812$2003^{9}$ (part I) was used compression of chemical properties of cement and fly ash shown in tabe 1 and EDAX result of fly ash are shown in figure 1 . The specific gravity of fly ash is 2.30 .

Table 1: Chemical composition of cement and fly Ash

\begin{tabular}{|c|c|c|}
\hline $\begin{array}{l}\text { Chemical } \\
(\mathrm{Wt} \%)\end{array}$ & Cement & Fly Ash \\
\hline $\mathrm{SiO}_{2}$ & 21.0 & 55.47 \\
\hline $\mathbf{A l}_{2} \mathbf{O}_{3}$ & 5.4 & 26.89 \\
\hline $\mathrm{Fe}_{2} \mathrm{O}_{3}$ & 3.3 & 4.34 \\
\hline $\mathrm{CaO}$ & 65.6 & 1.30 \\
\hline MgO & 1.1 & 0.58 \\
\hline $\mathrm{SO}_{3}$ & 2.7 & 0.90 \\
\hline $\mathrm{K}_{2} \mathrm{O}$ & - & 0.67 \\
\hline $\mathrm{TiO}_{2}$ & - & 1.30 \\
\hline $\mathrm{Na}_{2} \mathrm{O}$ & - & 0.98 \\
\hline LOI & 1.2 & 1.10 \\
\hline
\end{tabular}




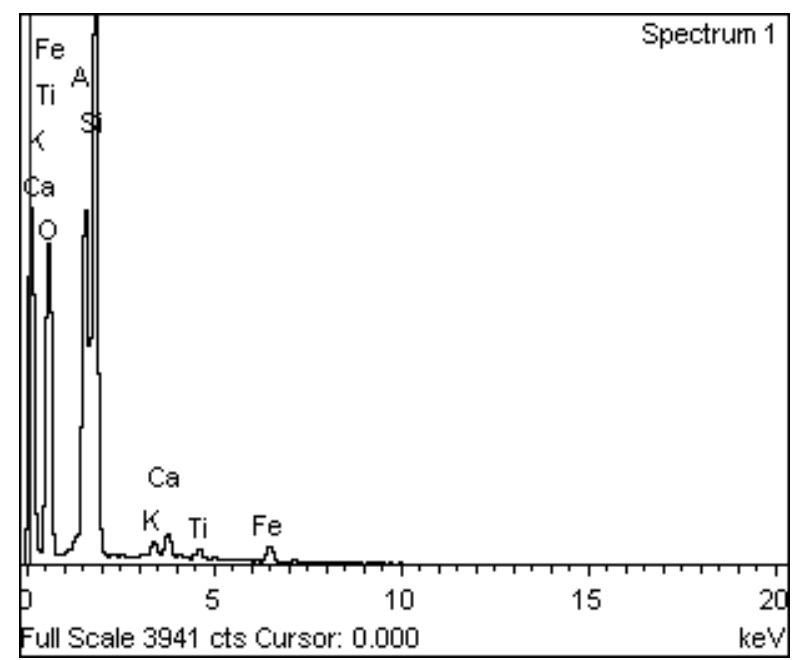

Fig 1: Edax result of Fly Ash

\subsection{Aggregates}

Coarse aggregates of $20 \mathrm{~mm}$ size obtained locally conforming to IS 383-1970 was used. The various properties of coarse aggregate and fine aggregate shown in table 2.Locally available river sand passing through IS $4.75 \mathrm{~mm}$ sieve conforming to zone II of IS 383-19709 (part 30 was used.

Table 2. Properties of Aggregate

\begin{tabular}{|c|c|c|c|c|c|}
\hline $\begin{array}{c}\text { S.N } \\
\text { o. }\end{array}$ & $\begin{array}{c}\text { Particula } \\
\text { rs }\end{array}$ & \multicolumn{2}{|c|}{ Fine Aggregate } & \multicolumn{2}{c|}{$\begin{array}{c}\text { Coarse } \\
\text { Aggregate }\end{array}$} \\
\hline \multirow{2}{*}{1.} & Specific & \multicolumn{2}{|c|}{2.56} & \multicolumn{2}{|c|}{2.79} \\
Gravity & \multicolumn{2}{|c|}{} & \multicolumn{2}{|c|}{} \\
\hline 2. & $\begin{array}{c}\text { Fineness } \\
\text { Modulus }\end{array}$ & \multicolumn{2}{|c|}{3.91} & \multicolumn{2}{|c|}{3.56} \\
\hline \multirow{2}{*}{3.} & $\begin{array}{c}\text { Bulk } \\
\text { Density }\end{array}$ & Loose & Rodded & Loose & Rodded \\
\cline { 3 - 6 } & & $\mathbf{1 . 6 4 0}$ & $\mathbf{1 . 7 2 8}$ & $\mathbf{1 . 4 1 4}$ & 1.420 \\
\hline
\end{tabular}

2.4 Fibres
Polypropylene fibres of monofilament type having $12 \mathrm{~mm}$ length were used for improve the mechanical properties and Durability properties of concrete.

\subsection{Admixtures}

Polycarboxylate ether based superplasticizer(SP) conforming to IS 9103-1999 was used to reduce the watercement ratio.

\subsection{Mix Proportion and Proportion of Specimen}

Six mixes were made. A reference mix was designed without fly ash replacement in accordance with 10262-2013 to target strength of $48.25 \mathrm{~N} / \mathrm{mm} 2$ at 28 days of curing. Four mixes were made with fly ash replacement in $40,50,55$ and $60 \%$ of ement. Polypropylene fibres were added at $0.2 \%$ to all five mixes. The water cement ratio was kept as 0.33 and super-plasticizer was added to all mixes at $0.8 \%$ of cementitious material. Table 3 shows the mix proportion of all mixes. Concrete mixtures were mixed using drum mixer and placed in required moulds. The concrete specimens were demolded after 24 hours and placed in curing tank for curing

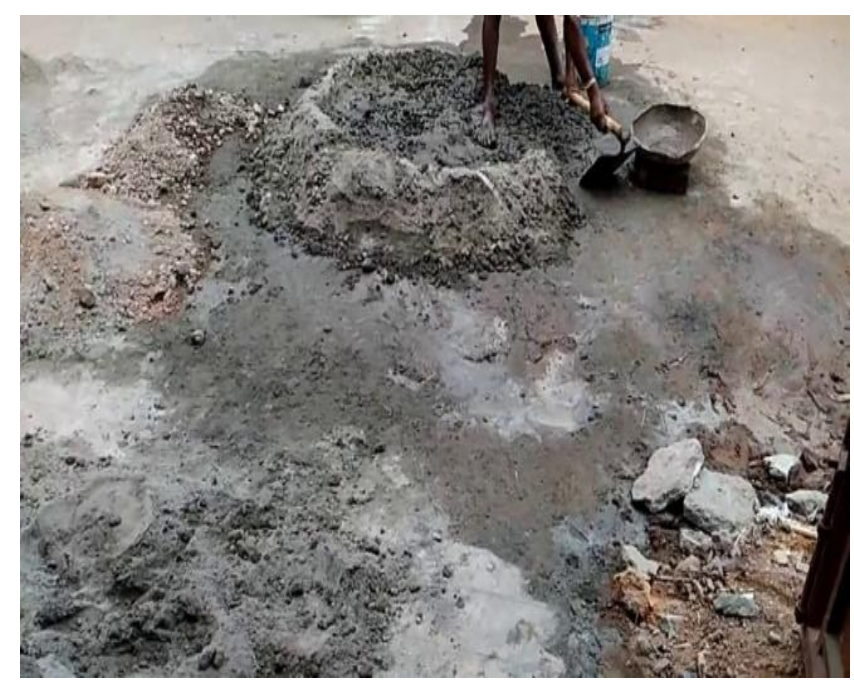

Fig 2: Mixing of concrete

\begin{tabular}{|c|c|c|c|c|c|c|c|c|c|c|c|c|}
\hline \multirow{2}{*}{$\begin{array}{c}\text { Mix } \\
\text { Designati } \\
\text { on }\end{array}$} & \multicolumn{2}{|c|}{ Cement } & \multicolumn{2}{|c|}{ Fly Ash } & \multirow{2}{*}{$\begin{array}{l}\text { FA } \\
\text { kg } \\
\end{array}$} & \multirow{2}{*}{$\begin{array}{l}\text { CA } \\
\mathrm{kg}\end{array}$} & \multirow{2}{*}{ W/C } & \multirow{2}{*}{$\begin{array}{c}\begin{array}{c}\text { Wate } \\
\text { r }\end{array} \\
\mathbf{k g} \\
\end{array}$} & \multicolumn{2}{|c|}{$\begin{array}{c}\text { Super } \\
\text { plasticizer }\end{array}$} & \multicolumn{2}{|c|}{ Fibre } \\
\hline & $\%$ & kg & $\%$ & kg & & & & & $\%$ & kg & $\%$ & $\mathbf{k g}$ \\
\hline M1 & 100 & 448 & 0 & 0 & 732 & 1125 & $\mathbf{0 . 3 3}$ & 148 & 0.8 & 2.24 & 0 & 0 \\
\hline M2 & 100 & 448 & 0 & 0 & 732 & 1125 & $\mathbf{0 . 3 3}$ & 148 & 0.8 & 2.24 & 0.2 & 1.8 \\
\hline M3 & 60 & 268.8 & 40 & 179.2 & 732 & 1125 & $\mathbf{0 . 3 3}$ & 148 & \begin{tabular}{c|}
0.8 \\
\end{tabular} & 2.24 & 0.2 & 1.8 \\
\hline M4 & 55 & 224 & 50 & 224 & 732 & 1125 & $\mathbf{0 . 3 3}$ & 148 & 0.8 & 2.24 & 0.2 & 1.8 \\
\hline M5 & 50 & 201.6 & 55 & 246.4 & 732 & 1125 & $\mathbf{0 . 3 3}$ & 148 & 0.8 & 2.24 & 0.2 & 1.8 \\
\hline M6 & 40 & 179.2 & 60 & 268.8 & 732 & 1125 & $\mathbf{0 . 3 3}$ & 148 & 0.8 & 2.24 & 0.2 & 1.8 \\
\hline
\end{tabular}

Table 3:Mix Proportion

\section{EXPERIMENTAL PROGRAM}

\subsection{Flexural Strength}

Flexural strength of concrete beam specimens was tested in accordance with IS 516:1959 in this study. The beam specimen of size $100 \mathrm{~mm} \times 1000 \mathrm{~mm} \times 500 \mathrm{~mm}$ was casted for testing the flexural strength. Average of three specimens tested in each mix is considered as the flexural strength of the concrete.

\subsection{Sulphate Resistance test}

The test was carried out in order to study the effect of high volume flyash on the resistance against magnesium sulfate attack. The $100 \times 100 \times 100 \mathrm{~mm}$ concrete cube specimens were cast and cured in water for 28 days. Magnesium Sulphate is used as the chemical in this test.

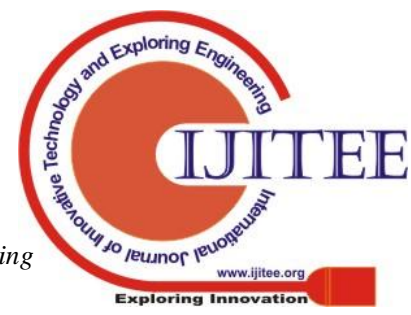




\subsection{Chloride Resistance test}

The test was carried out in order to study the effect of high volume flyash on the resistance against chloride attack. The $100 \times 100 \times 100 \mathrm{~mm}$ concrete cube specimens were cast and cured in water for 28 days. Sodium Chloride is used as the chemical in this test.

\subsection{Rapid Chloride Penetration Test}

The test was performed on cylindrical specimens of diameter $100 \mathrm{~mm}$ and height $200 \mathrm{~mm}$ to determine the rate of permeability as per ASTM C 1202 (2009).

\subsection{Water absorption test}

This test was carried on hardened concrete specimens (BS 1881: Part122, 1983). The $100 \times 100 \times 100$ mmcube specimen were prepared and cured for 28 days to find the percentage of water absorbed by the specimen.

\section{RESULT AND DISCUSSION}

\subsection{Flexural Strength}

Flexural strength of all mixes was determined at the age of 28 days. Table. 4 shows the flexural strength of all mixes. From table.4, it can be noted that, the flexural strength of concrete increases with the addition of fibre and flyash. By addition of fibre, the fibre acts as a bridge between cracks and reduces the formation of cracks. This action of fibre bridging increases the flexural strength of concrete. From fig.3, it can be noted that the flexural strength increases with the increase in flyashcontent upto $50 \%$ and thereafter decreases. The increase in flexural strength is due to the secondary CSH gel formed by the pozzolanic action of flyash.

Table 4: Flexural strength

\begin{tabular}{|c|c|}
\hline Mix & Flexural Strength in $\mathbf{~} / \mathbf{m m}^{2}$ \\
\hline M1 & 6.27 \\
\hline M2 & 6.4 \\
\hline M3 & 6.8 \\
\hline M4 & 6.92 \\
\hline M5 & 6.53 \\
\hline M6 & 5.73 \\
\hline
\end{tabular}

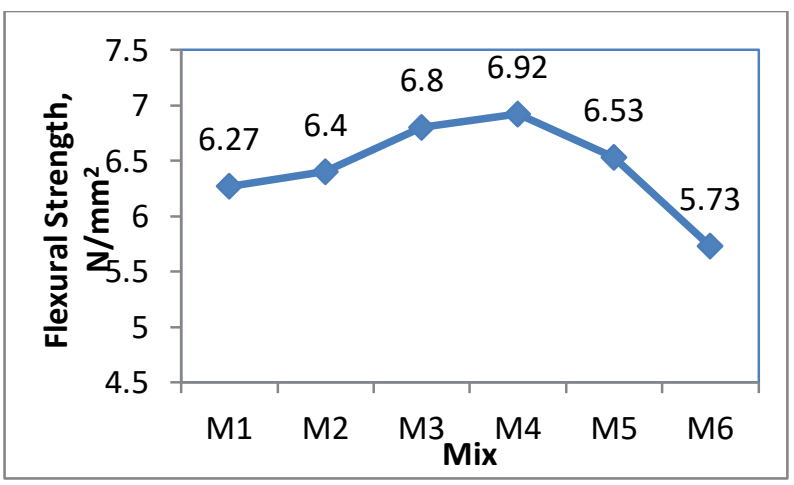

Fig3: Flexural strength

\subsection{Sulphate Resistance test}

Sulphate resistance of concrete was tested after 28 days for the reference mix and the optimum mix. Table.5. and fig. 5 shows the values of weight loss and strength loss due to sulfate attack. From table.5 it can be noted that the sulfate resistance of concrete increased with the addition of flyash and fibre.Fig.4, shows the weight loss and strength loss of concrete specimens due to sulfate solution.

Table 5: Strength loss and weight loss due to sulfate attack

\begin{tabular}{|c|c|c|}
\hline Mix & Weight loss (\%) & Strength loss (\%) \\
\hline M1 & $\mathbf{0 . 2 7 8 4}$ & 9.28 \\
\hline M2 & $\mathbf{0 . 2 3 1 8}$ & $\mathbf{8 . 1 6 6 7}$ \\
\hline M5 & $\mathbf{0 . 1 1 5 9}$ & 5.9738 \\
\hline
\end{tabular}

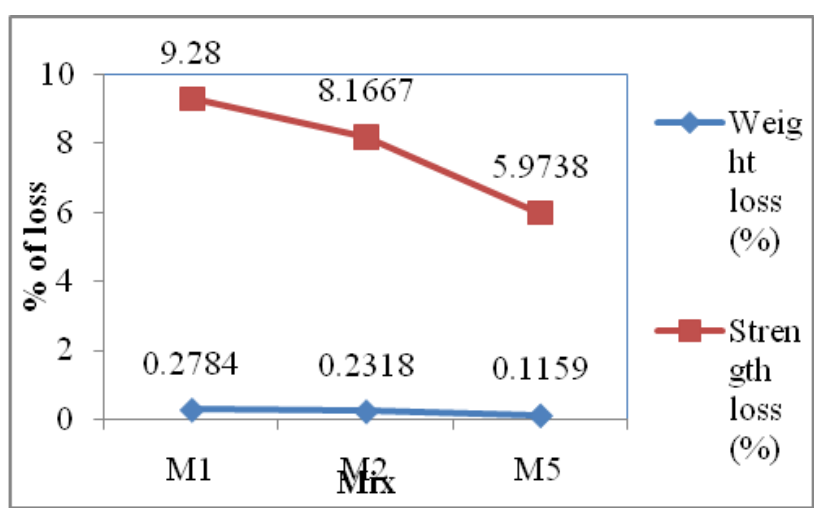

Fig 4: Weight loss and strength loss due to sulfate attack

\subsection{ChlorideResistance test}

Chloride resistance of concrete was tested by immersion of concrete cubes in $0.5 \%$ Nacl solution after 28 days of curing. Table.6. shows the weight loss and strength loss due to chloride attack. From table.6.it can be noted that the addition of fibre and flyash increases the resistivity of concrete towards chloride attack. The formation of secondary $\mathrm{CSH}$ gel reduces the pore voids in concrete and thereby increases the resistivity towards sulfate attack. Fig.5.shows the cumulative weight loss of concrete specimens due to chloride attack. Fig.6. indicates that the mix with $55 \%$ flyash and $0.2 \%$ polypropylene fibre showed the lowest value of weight loss and strength loss due to chloride attack. The mix with $55 \%$ flyash and $0.2 \%$ polypropylene fibre offered greater resistivity towards chloride attack.

Table 6: Strength loss and weight loss due to chloride attack

\begin{tabular}{|c|c|c|}
\hline Mix & Weight loss (\%) & Strength loss (\%) \\
\hline M1 & $\mathbf{0 . 2 3 0 8}$ & 12.312 \\
\hline M2 & $\mathbf{0 . 1 9 1 7}$ & $\mathbf{1 0 . 1 2 5}$ \\
\hline M5 & $\mathbf{0 . 0 7 8 5}$ & $\mathbf{7 . 1 3 9 9}$ \\
\hline
\end{tabular}




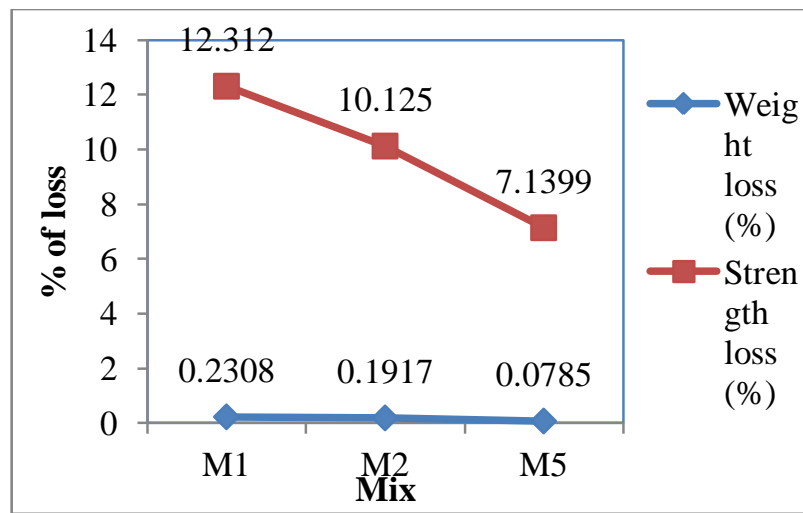

Fig 5: Weight loss and strength loss due to chloride attack

\subsection{Rapid Chloride Penetration Test}

RCPT was done in concrete specimens after 28 days of curing. Table.7 shows the RCPT results. From table.7, it can be noted the mix with $55 \%$ flyash and $0.2 \%$ polypropylene fibre showed the lowest chloride permeability. This maybe due to action of fibre bridging and the formation of secondary $\mathrm{CSH}$ gel

Table 7: RCPT Results

\begin{tabular}{|c|c|c|}
\hline Mix & $\begin{array}{c}\text { Charge } \\
\text { passed in } \\
\text { coulombs }\end{array}$ & $\begin{array}{c}\text { Permeability class as } \\
\text { per ASTM C 1202 }\end{array}$ \\
\hline M1 & 903 & Very low \\
\hline M2 & 783 & Very low \\
\hline M5 & 102 & Very low \\
\hline
\end{tabular}

\subsection{Water Absorption Test}

Water absorption of concrete specimens was found out at the age of 28 days curing. Table.8.7 shows the water absorption values. Table. 8 indicates that the mix with $55 \%$ flyash and $0.2 \%$ polypropylene fibre had the lowest value of water absorption. The reduction in water absorption values maybe due to the formation of secondary CSH gel. The secondary CSH fills the capillary pores in concrete and hence reduces the water absorption in concrete

Table 8: Water absorption Test

\begin{tabular}{|c|c|}
\hline Mix & \% of water absorption \\
\hline M1 & 3.6 \\
\hline M2 & 1.91 \\
\hline M5 & 0.85 \\
\hline
\end{tabular}

\section{CONCLUSION}

From, the experimental results, the following conclusion can be drawn:

1. The 7 days strength decreased with increase in fly ash content

2. The results show that high volume fly ash concrete with polypropylene fibre attained higher strength at a later days on flexural strength.

3. The mix M5 with $55 \%$ flyash and $0.2 \%$ polypropylene fibre is considered as the optimum mix since at higher replacement the mix showed higher strength than the reference mix
4. Optimum mix (M5) showed high sulphate resistance and chloride resistance in terms of strength loss and weight loss.

5. Permeability level of high volume fly ash concrete with polypropylene fibre was very low, considerable amount of charge passed is 102 Coulombs only.

6. High volume flyash concrete with polypropylene fibre offered a greater resistance to water absorption compared to reference concrete.

7. High volume flyash concrete with polypropylene fibre enhanced the durability properties of concrete

\section{REFERENCES}

1. ASTM C 1202, 2009. Standard test method for electrical indication of concrete's ability to resist chloride ion penetration.

2. BS 1881: Part 122, 1983. Testing Concrete-Method for Determination of Water Absorption. British Standards Institution, London.

3. BIS-2386-1963 (Part I\&III), "Method of test for Aggregate for concrete", Bureau of Indian Standards, New Delhi.

4. BIS: 383-1970, "Specification for coarse and fine aggregates from the natural sources for concrete", Bureau of Indian Standards, New Delhi.

5. BIS: 10262-2009, "Concrete mix proportioningGuidelines", Bureau of Indian standards, New Delhi.

6. 6. BIS 516-1959, "Method of Tests for Strength of Concrete", Bureau of Indian standards, New Delhi.

7. BIS:1199-1959, "Methods of sampling and analysis of concrete", Bureau of Indian standards, New Delhi.

8. IS: 9103-1999, "Specification for concrete admixtures", Bureau of Indian standards, New Delhi.

9. B. Balakrishnan, A.S.M. Abdul Awal, "Mechanical Properties and Thermal Resistance of High Volume Fly Ash Concrete for Energy Efficiency in Building Construction", Key Engineering Materials, Vol.678, 2016, pp. $99-108$

10. Chung-Ho Huang, Shu-Ken Lin, Chao-Shun Chang, HowJiChenb"Mix proportions and mechanical properties of concrete containing very high-volume of Class F fly ash", Construction and Building Materials, Vol.46, 2013, pp.7178

11. C.S. Poon, L. Lam, Y.L. Wong, “A study on high strength concrete prepared with large volumes of low calcium fly ash", Cement and Concrete Research, Vol.30, 2000,pp.447-455

12. F.U.A. Shaikh, S.W.M. Supit, "Compressive strength and durability properties of high volume fly ash (HVFA) concretes containing ultrafine fly ash (UFFA)", Construction and Building Materials, Vol.82, 2015, pp.192-205

13. L.H. Jiang, V.M. Malhotra, "Reduction in water demand of non-air-entrained concrete incorporating large volumes of fly ash" Cement and Concrete Research, Vol.30, 2000, pp.1785-1789

14. OkanKarahan, Cengiz Duran Atis, "The durability properties of polypropylene fiber reinforced fly ash concrete", Materials and Design, Vol.32, 2011, pp.10441049

15. O. Kayali, "Effect of high volume fly ash on mechanical properties of fiber reinforced concrete", Materials and Structures, Vol.37, 2004, pp.318-327 